\title{
A role for cGMP-dependent protein kinase II in AMPA receptor trafficking and synaptic plasticity
} Yafelle Serulle ${ }^{1,3}$, Ipe Ninan ${ }^{2,4}$, Daniela Puzzo 2,5, Maria McCarthy1,6, Latika Khatri ${ }^{1}$, Ottavio Arancio ${ }^{2}$ and Edward Ziff*1

\author{
Address: ${ }^{1}$ Department of Biochemistry, NYU Langone Medical Center, New York NY 10016, USA, ${ }^{2}$ Department of Pathology and Taub Institute, \\ Columbia University, New York, NY, 10032, USA, 32Department of Physiology, NYU Langone Medical Center, New York NY 10012, USA, \\ ${ }^{4}$ Department of Psychiatry, NYU Langone Medical Center, New York NY 10012, USA, ${ }^{5}$ Department of Physiological Sciences, Viale A. Doria, 6 ,

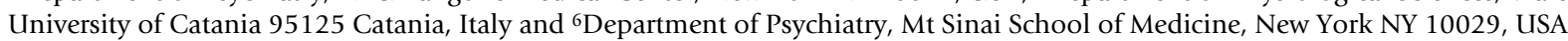 \\ Email: Edward Ziff* - edward.ziff@nyumc.org \\ * Corresponding author
}

from 4th International Conference of cGMP Generators, Effectors and Therapeutic Implications

Regensburg, Germany. 19-21 June 2009

Published: II August 2009

BMC Pharmacology 2009, 9(Suppl I):S44 doi:10.1186/147I-2210-9-SI-S44

This abstract is available from: http://www.biomedcentral.com/I47I-22I0/9/SI/S44

(c) 2009 Serulle et al; licensee BioMed Central Ltd.

\section{Background}

Trafficking of AMPA receptors (AMPARs) underlies the activity-dependent modification of synaptic strength and is regulated by specific interactions of AMPAR subunits with other proteins. We have reported (Serulle et al., 2007) [1] that the AMPAR subunit GluR1 binds the cGMP-dependent kinase type II (cGKII) adjacent to the kinase catalytic site, and that this interaction is increased by cGMP. In this complex, cGKII phosphorylates GluR1 at serine 845 (S845) leading to an increase of GluR1 on the plasma membrane. In neurons, cGMP is produced by soluble guanylate cyclase (sGC), which is activated by nitric oxide (NO), which is produced by nNOS under the control of the NMDA receptor.

\section{Results}

To distinguish the mechanism, we have measured the rate of exogenous GluR1 endocytosis in cultured primary neurons, either the wild type or the S845A or S845D mutants (Figure 1). We find that the S845A mutant (which cannot be phosphorylated) is endocytosed at rate of the wild type, while S845D (phosphomimetic) is endocytosed at a lower rate. Also, cGMP treatment, which elevates the endogenous GluR1 plasma membrane levels (Figure 2A), reduced the rate of of GluR1 endocytosis (Figure 2B).
Endocytosis of HA-GluR1 to Early Endosomes

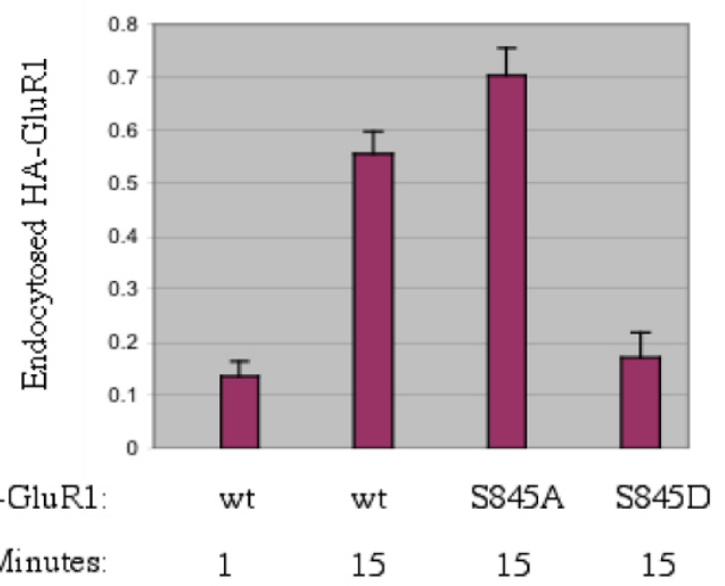

Figure I

Endocytosis of HAGluRI is time dependent and is inhibited by the phosphomimetic mutation, S845D. 
A

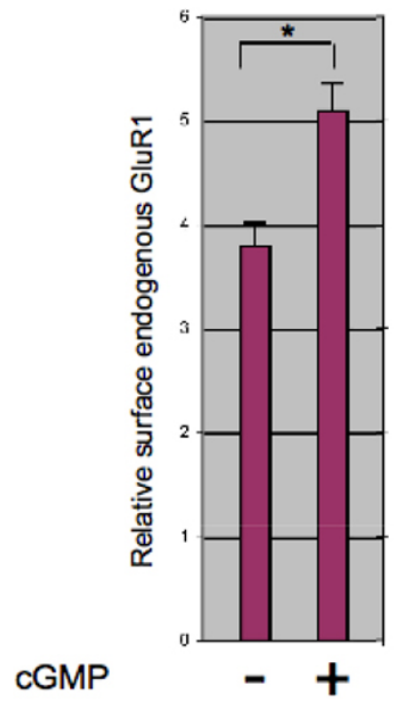

B

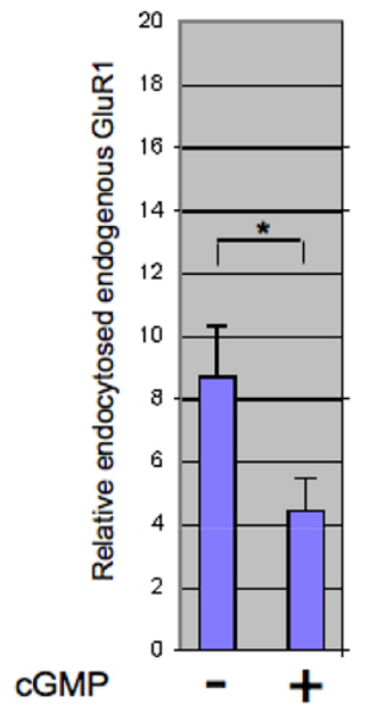

Figure 2

Elevation of surface GluR I and reduction of GluR I endocytosis by cGMP. A. cGMP, elevates surface GluRI. B. cGMP decreases endocytosis of GluRI.

\section{Conclusion}

These data suggest that S845 phosphorylation increases the plasma membrane levels of GluR1 by reducing the rate of endocytosis.

\section{References}

I. Serulle Y, Zhang S, Ninan I, Puzzo D, McCarthy M, Khatri L, Arancio O, Ziff EB: A GluRI-cGKII interaction regulates AMPA receptor trafficking. Neuron 2007, 56:670-688.

Publish with Bio Med Central and every scientist can read your work free of charge

"BioMed Central will be the most significant development for disseminating the results of biomedical research in our lifetime."

Sir Paul Nurse, Cancer Research UK

Your research papers will be:

- available free of charge to the entire biomedical community

- peer reviewed and published immediately upon acceptance

- cited in PubMed and archived on PubMed Central

- yours - you keep the copyright 